\title{
Understanding the Gender Regime in the European External Action Service
}

\author{
Dr Laura Chappell and Prof Roberta Guerrina
}

\section{Introduction}

Since the inclusion of the Common Foreign and Security Policy (CFSP) within the Maastricht Treaty (1992), the EU has set out to become a key foreign policy actor to complement its expanding economic role. Through the creation of new institutions and policy instruments, the EU has enhanced its role in the international arena, thus presenting it with an opportunity to promote its interest and norms externally. Key to understanding the role of the EU as an external actor is the role of fundamental values, as established by the Treaties. These define the scope of EU action, its role and ambition. It is thus interesting to note that research looking at the diffusion of foundational norms from the communitarised fields to external affairs has been lacking. Aside from the debate instigated by Manners' (2002) work on Normative Power Europe, the focus of mainstream research has been on the position of security and defence, as policy domains, within the architecture of the EU. Although the focus of our analysis seeks to advance the research on gender and CSDP, it also provides important insights for feminist security scholars by introducing the concept of gender regimes to the field of security studies.

This article thus sets out to investigate the role of the EU as a gender actor in foreign and security policy particularly focusing on where gender can be located institutionally and with respect to promoting gender norms as part of the CSDP portfolio. Gender equality is often cited as a foundational norm of the EU, particularly in the communitised fields, e.g. employment (MacRae, 2010). As Kronsell (2012: 114) explains, the EU's role as an actor in external affairs, 'emerged in a context in which gender equality policies and gender mainstreaming were already well known in other policy areas in the EU'. This thus points to the impact of the internal dynamics, practices and structures on policy outcomes. For instance, Kronsell draws attention to military gender regimes in the EU military committee. It should therefore follow that the institutionalization of foreign and security policy would lead to greater opportunities for the inclusion of a gender sensitive approach in this policy field. The diffusion of this norm into areas of foreign and security policy, however, remains largely on the margins. What this means is that gender appears as a set of specific recommendations on WPS, gender equality and/or women's empowerment, but has not yet been mainstreamed to all areas of foreign policy, security and defence. (Guerrina et al, 2018). 
Our research puzzle relates to this tension between what the Treaties, and key institutional actors, say are core EU values, e.g. equality and mainstreaming, and what the EU does to operationalise those values in areas of "high politics" that are traditionally seen as gender neutral/free. The starting point for this analysis is a recognition that institutions are themselves gendered and shaped by complex processes, values and structures constitutive of particular gender regimes and/or gender orders (Weiner and MacRae, 2014). Our analysis turns to the EEAS as a site for gender politics posing the following research question: Where is gender equality, as a policy frame, located within the EEAS? This overarching question allows us to map how the principles of equality and gender mainstreaming, as defined by the Treaties, have permeated this policy domain, and open a space for our second research question: How does the European External Action Service reflect the EU's gender regime and, how does this shape the (mainstream) policies that are developed by this institution?

Understanding the role of the EU as a gender actor across a variety of policy domains provides important insights into the continuous development of a European gender regime that results from a process of negotiation, adaptation and contestation between different components of the EU. This analysis thus highlights the continuous process of adjustment that drives what is essentially a gender regime in transition, its impact on Member States, and the opportunities for promoting equality policies in a transnational setting. Moreover, considering the dearth of literature on gender and foreign policy, let alone the impact of gender norms on the European external dimension, this article will contextualize the analysis by focusing on the distinct body of literature on gender regimes. Our article will thus explore the nature of the EU's gender regime/s and how it has diffused to non-communitised areas, e.g. CSDP. If indeed what matters is what the EU is, rather than what it does, then exposing the way the gender regime permeates all areas of work and activity, provides important insights into the way the EU is developing as a gender actor. The article will thus turn to the key debates surrounding the role of the EEAS and the EU as an external actor. This will include the design of the EEAS as underlined in the Lisbon Treaty and subsequent EU documentation as well as the central arguments and ideas pertaining to its role and function. Finally, we will present initial empirical evidence in regards to where gender can be found within the EEAS including personnel, institutional positioning and policy areas. What this analysis highlights is that whilst gender has certainly been flagged up as an issue in respect of staffing, gender norms have yet to be integrated to any meaningful 
extent in the EEAS. This approach to gender mainstreaming, we argue ultimately has implications for the type of foreign policy the EU pursues.

This article makes a contribution to two bodies of literature. Firstly, it highlights the significance of gender, as an analytical lens, to the study of global governance, norms and institutions. In so doing so, it draws attention to the way gender and intersectional issues have largely been ignored by the mainstream literature, but have in fact produced structures and institutions that exclude the interests of under-represented groups. Secondly, this article contributes to the growing body of research on UN Security Council Resolution 1325 and the Women, Peace and Security Agenda. Whereas much of this literature has focused on the ratification of the original UNSCR1325, the development of this policy agenda at the UN, and the way such norms have travelled when adopted by States through National Action Plans, it has largely overlooked international or regional organisations. Wright (2016) points to the importance of exploring how global gender norms are adapted and transformed when security organisations adopt WPS as one of their working principles. Our article thus provides important insights into the competing pressures faced by a complex organization as it seeks to pursue a strategic approach to WPS in the context of a gender equality agenda that has evolved over the lifetime of the organization and have shaped its internal gender regime.

\section{Normative gender actor or gendered normative actor?}

This section explores the underlying values, principles and policies that define the EU as a gender regime. It provides the main conceptual framework for our analysis of the way the key foundational norms have been incorporated in the fields of foreign, security and defence policy. This analysis focuses on how the EU's being shapes how the EEAS approaches mainstreaming gender in this policy area. In this way, we consider the extent to which the EU, and the EEAS in particular, reflect on the application of their core values, e.g. equality, within the organisation before they set about promoting those same values to third countries (David and Guerrina, 2013).

Through this analysis we intend to differentiate between normative gender actors, i.e. those that actively promote equality principles and mainstreaming, and gendered normative actors, i.e. those that only strategically deploy gender narratives. In this case, we thus ask which kind of normative actor is the EU in security and defence, when we apply gender sensitive lenses to this analysis. 
Walby's gender regime theory introduces a useful framework for the analysis of the way gender, as a structure of power, permeates institutions and shapes social dynamics and relations. In her own words, 'a gender regime is a set of inter-related gendered social relations and gendered institutions that constitute a system' (Walby, 2009: loc 6034). Stemming from feminist critiques of welfare regimes theories, this framework exposes the role of hierarchies on cross-cutting socio-economic systems and their impact on promoting equality.

Gender regime theory has been applied mostly to the analysis of social, employment and welfare policies. Walby's (2004: 10) framework concentrates on social practices and hierarchies and the way they influence policy processes and outcomes. Gender regimes therefore operate at the state-economy-society nexus and influence how gender relations are structured within the family, the employment market and state institutions. The analysis of gender regimes reveals the importance of social hierarchies (e.g. gendered work, individualism) and economic structures (e.g. neo-liberalism and competition) on equality outcomes (Walby, 2009). Moreover, gender regimes are neither fixed nor internally homogeneous.

Connell's (2005) formulation of gender regimes develops this analysis further. Looking specifically at the role of organisations as 'the bearers of gender relations' (Connell, 2005: 1). In this context, a gender regime is a system that organises social, political and economic relations, as she explains, "By the "gender regime" of an institution we mean the patterning of gender relations in that institution, and especially the continuing pattern, which provides the structural context of particular relationships and individual practices' (Connell, 2005: 6). Gender regimes are defined by interfacing dimensions: 1. divisions of labour; 2. gender relations of power; 3. human relations; 4. gender culture and symbolism (Connell, 2005: 7). Gender regime theory ultimately highlights that policy silences should not be taken to imply that a policy domain is gender free or neutral. Rather, different gender regimes shape the very way policy domains pursue equality, thus exposing the work gender, as a structure of power is doing in those areas of policy where gender is "invisible". It is the "gender identity" of a policy regime.

The EU's gender regime is grounded in the development of an extensive body of equality policies/legislation in the sphere of employment between 1975 and the early 2000s, which 
institutionalised core principles, processes and practices associated with the advancement of the European equality agenda (Walby, 2004; Guerrina, 2005; Woodward \& van der Vleuten, 2014). The adoption of institutional narratives, which position equality as a foundational principle of European integration, further augment the institutionalisation of its gender regime (MacRae, 2010).

Walby's analysis points out opportunities and constraints offered to the European "gender machinery" to affect change in different Directorate Generals. Understanding the relationship between the EU's gender regimes, its relationship to the plurality of Member States' gender regimes, and the individual gender regimes of each institution is particularly important to understand the role of the EEAS as a normative gender actor. In order to do this, we need to expand Walby's understanding of gender regime, beyond the interaction between public and private domains, to focus on the wider set of interactions, structures and systems that shape the gender regime within the institution itself.

Whilst Walby (2009) does not focus on norms as one of the foundations of gender regimes, it is clear that they are the scaffolding upon which gender regimes rely. This addition to gender regime theory is important in the analysis of the EU as a gender actor. The EU's own approach to promoting the equality principle is rooted in the Treaties, and since Amsterdam (1998) it revolves around gender mainstreaming $(\mathrm{GM})$. It is not for this article to explore the opportunities and constraints embedded in this approach (for a detailed analysis see Minto and Mergaert, 2018; Pollack and Hafner-Burton, 2000; O’Connor, 2014). However, GM represents a highly institutionalized form of internal norm diffusion. As a strategy, and/or form of governance, it is predicated on the inclusion of a gender dimension to all policy areas, including external affairs. It is about transforming the very nature of the institutions through recognition that gender permeates all policy domains. As such, it should have a distinct impact on the gender regime of the EU as a whole, and specifically of those areas of policy, e.g. external action, where gender has been largely ignored or invisible. At least that is how it is supposed to work in theory. It is also important to recognise the impact of institutional inertial and obstacles to the GM across all policy domains, as Cavaghan's (2016: 52) analysis points out the difficulty in translating principles and values into 'clearly stipulated processes'. So, the question for us here is whether the EU's approach to promoting the equality principle within its own organisational architecture shape the way it goes about formulating its strategic approach to external action. 
Woodward and van der Vleuten (2014: loc 1666) point out that 'the recognition of equality between women and men in the EU's primary law is thus a significant part of its gender regime'. Gender mainstreaming, and its formal extension to external relations, is key to understanding the emergence of the EU as a gender regime. Specifically, it opens the opportunity for engagement outside the area of employment and social affairs. The other area of significance, in relation to the development of the EU as a gender actor and regime is the role of institutions and institutional actors. Woodward \& van der Vleuten (2014: loc 17021714), point out that

'The EU has developed a sophisticated gender machinery, and over the years, this has evolved into forming what can be termed a model of 'state' feminism where the machinery of the state is used to advance the goals of women's movement activism'.

This is particularly significant in relation to the advisory committees in the European Commission and the FEMM committee in the European Parliament. In relation to the external dimension, directorates seeking to implement gender mainstreaming are present in DG Development. However, Woodward \& van der Vleuten (2014) found no such equivalent in DG Trade. This article looks at the way gender has been mainstreamed within the EEAS. As will be discussed in the empirical section, we have also found very little evidence of mainstreaming in this sphere of external affairs.

This analysis opens up the possibility that institutions adopt specific gender regimes. Woodward \& van der Vleuten (2014: loc 1640) explain:

'How norms for gender equality are institutionalized in the EU arena is crucial in affecting the extent to which they are exported.... The EU gender regime includes both the formal legally binding norms, institutional actors and expert networks, as well as informal statements, declarations and practices reinforced with interactions at the numerous conferences and events organized by each presidency and by the major institutions of the EU'.

This is why the analysis of the EEAS is so important because it is the main vehicle for EU level diplomacy. It therefore follows that the value that the institution places on gender mainstreaming reflects its own gender regime, which is supposed to draw on the key values of the organization, but in reality may be different from that reflected in the internal dimension. It is this relationship that we explore in this paper. 
Women's absence in European security and defence negotiations is pervasive. Kronsell (2012) explored the lack of a meaningful engagement with gender issues and concludes that: 'gender imbalance of the EU's member states' national militaries explains the gender gap in EU missions, battle-groups and decision-making bodies'. There are two ways that gender has often been included in mainstreaming considerations about foreign policy, security and defence. Institutions have either adopted an "add women and stir" approach to equality or have sought to coopt gender norms in the pursuit of "higher political priorities" (Jaquette, 2011; Ruane, 2011). This paper will explore the EEAS's approach to mainstreaming gender, therefore mapping its emergence as a distinct gender regime.

\section{Introducing the EEAS}

The establishment of the EEAS represents significant institutional innovation in the area of security and defence, and an opportunity for gender champions to integrate a gender perspective in a policy domain that is traditionally portrayed as "gender neutral". The main aim of the EEAS is to bring consistency and coherence in the development of European foreign policy, thus enabling the organization to use the full spectrum of instruments at its disposal in pursuit of the common interest. In attempting to combine the civilian and military elements of foreign policy, it becomes the main diplomatic tool for the advancement of EU foreign policy and the vehicle for norms diffusion in an international setting. As such, the EEAS takes on the responsibility for gender mainstreaming (GM) in foreign and security policy. Nine years since the introduction of the Lisbon Treaty in 2009, it is now an opportune moment to conduct an initial assessment of the role of this institution in promoting EU gender norms in the external dimension. This links in with the idea of the EU as a normative power and its ability to hold and promote these norms. The focus of our analysis here is on practices, structures and their impact on shaping the normative underpinning of this policy domain. This analysis will draw attention to how the EU's gender regime is reproduced or transformed through the process of mainstreaming gender into external affairs.

In a nutshell, the EEAS was one of the key innovations set out in the Lisbon Treaty and is a 'significant milestone' in which foreign policy cooperation was moved away from national capitals and into Brussels (Vanhoonacker \& Pomorska, 2013: 1319). Headed by the High Representative for Foreign Affairs and Security Policy (HR), the key aim was to provide the EU with a 'diplomatic service'. Both of these were necessary to ensure continuity of the EU's foreign policy rather than the agenda being dictated by the six-month rotating Presidency. 
No detail was given within the Lisbon Treaty concerning the institutional layout of the EEAS or its responsibilities. Instead it was the first HR Baroness Catherine Ashton who was tasked with creating the institution. In her explanatory memorandum she stipulated that the EEAS 'will help strengthen the European Union on the global stage, give it more profile, and enable it to project its interests and values more efficiently' (Council of the European Union, 2010: 2). If equality is indeed a foundational value of the EU and a core pillar of the EU's gender regime, we would thus expect that it should be projected by the EEAS.

The final institutional layout of the EEAS was set out in the 2010 Council Framework Decision. Within the Framework Decision the EEAS key tasks were outlined as supporting the HR to fulfil her duties in respect of CFSP and CSDP (Council of the European Union 2010a: 32). The initial focus was on building the EEAS from the ground up and attempting to create an institution which was both capable and credible. It brought together civil servants from DG Relex and parts of DG Development within the Commission and DG External and PoliticoMilitary Affairs within the Council Secretariat as well as seconded national officials (see Vanhoonacker \& Pomorska, 2013: 1321-2, Council of the European Union 2010a). Additionally, EU delegations to third countries and international organisations were moved from the Commission to the EEAS. This is important, as the individuals joining the EEAS brought with them distinct expectations about the scope and purpose of external affairs.

Meanwhile Bátora (2013: 599) conceptualizes the EEAS as an interstitial organization which combines conflicting principles, practices and expectations. These come from foreign ministries and diplomatic services, defence ministries and crisis management agencies and global corporations with the latter influencing the 'internal governance mechanisms of the EEAS' (Bátora 2013: 607-8). Thus the EEAS may become an 'innovative kind of diplomatic agency' (Bátora 2013: 610). This presents a more positive view of the EEAS as a potential actor and its ability to create a unique set of roles. Shepherd (2016) also points to problems and opportunities. On the one hand stove-piping continues to be an issue in respect to the way different parts of the organisation work together, whilst on the other hand the EEAS has 'the potential to enhance inter-institutional coordination and better connect CSDP with internal security' (Shepherd 2016: 96). When connecting each of the three areas with a gender perspective it is clear that the first element (how the EEAS fits into the EU's institutional structure) should be taken as context. Whilst this is important not least because gender as a 
norm stems from communitised areas located in other institutions, the concentration of this article relates to the institutional construction of the EEAS and its initial policy focus in respect to integrating a gender perspective. As such the rest of this section will concentrate on these two elements.

Regarding the internal creation of the EEAS, focus has been placed on the ability of the institution to create an esprit de corps (see Missiroli 2010; Davis Cross 2011; Vanhoonaker and Pomorska 2013). However the differing institutional backgrounds of EEAS staff are also likely to include 'organizational and cultural clashes' (Davis Cross 2011: 454). It is these structural obstacles, along with lack of training strategy (Juncos and Pomorska 2014: 316) and the clashes between competing institutional (intergovernmental vs supranational) logics (Henökl, 2015: 679), which hamper the creation of a common culture (Vanhoonacker and Pomorska 2013: 1316).

Thus it is important to highlight the impact of such a system on foundational narratives within the EEAS. In one of the few pieces of work to focus on women and the EEAS, Novotnà (2015), finds that women are under-represented throughout the EEAS despite some progress. In particular, 'the increase in women staff was least evident in the key decision-making positions such as the EEAS senior management' (Novotnà 2015: 427; 428-9). This is despite Ashton's personal commitment and her role in selecting senior appointments along with Helga Schmidt's role in the professional development of women in the EEAS (Duke, 2014: 41). From a sociological perspective, another area of exploration relates to the extent to which gender is intertwined with EU officials' identification with the EU and its foreign policy. This interconnects with an esprit de corps because if a gender regime based on mainstreaming is to develop it will have to integrate a gender dimension for such a norm to take hold.

Finally, in terms of the EU's role as a gender and normative actor in external affairs, the focus of the literature is on issue areas and the extent to which the EEAS can be an autonomous actor (see Furness, 2013). Ashton in particular thought of the EU as a 'civilizing force' reflecting the EU's normative approach (Vanhoonacker and Pomorska 2013: 1326). Meanwhile Bátora (2013: 606) points to a range of tasks given to the EEAS under external action including not just diplomacy but also 'political engagement, development assistance and civil and military crisis management'. These tasks have met with mixed success as the EU's delayed reaction to the Arab Spring on the one hand whilst being pro-active in respect to the Western Balkans 
effectively demonstrates. Meanwhile CSDP was sidelined under Ashton. Hence considering the importance of the civilian dimension to the EEAS role, this might imply that gender mainstreaming becomes easier than might otherwise be the case with a more defence led agenda due its existence in communitised EU policies. Of key concern is the EU's lack of strategy which impinges on the EEAS' ability to set priorities 'because they will not have a strong sense of the organization's interests beyond maximizing its own bureaucratic responsibilities' (Furness 2013: 124). In linking this to a normative gender dimension, this raises questions concerning the EEAS' ability to promote it in the context of EU Member States' conflicting opinions which circumscribes EEAS action.

Hence what this brief overview of literature on the EEAS demonstrates is the complexity of designing, developing and implementing an institution which has to integrate both supranational and intergovernmental elements of EU foreign policy. This includes integrating officials from each part of the EU and cooperation with Member States and the Commission on relevant policy measures whilst trying to instill a sense of esprit de corps including a common normative commitment to EU foreign policy and the objectives such a policy should achieve. Hence uncovering gender in the EEAS is no easy task. First a common normative stance within the EEAS has not yet fully evolved indicating that where a gender perspective does occur it is unlikely to have dispersed across the EEAS. Hence there may well be 'pockets' of gender actorness but not full gender mainstreaming. From an institutional perspective this relates not only to how many women are working within the EEAS but also whether officials are looking at EU foreign policy through a gender lens. Finally, on a positive note, the various contestations regarding the position and design of the EEAS as well as its policy agenda could provide an opportunity for gender champions to cement a gender norm into the working of the EEAS.

\section{The EEAS as a gender equality actor?}

This section underscores where the principle of gender equality can be located in the EEAS by focusing on two key elements: personnel and security and defence policy. The first underscores how the EEAS has integrated a gender perspective into its personnel policies. This is important because it allows us to highlight how far the EU's legal and normative underpinnings are reflected in its own internal practices (starting with staffing and the very fabric of its institutional architecture). It also connects to the work already conducted on gender regimes in employment as highlighted above. Hence we can provide insights into the EEAS as an equal 
opportunity employer. The second highlights where gender can be found in policy documents dealing with policy areas which come under the responsibility of the EEAS. We have chosen to focus on CSDP, first because institutionally the policy is dealt with primarily in the EEAS rather than the Commission. Second, traditionally CSDP is seen as being 'gender neutral/free' with a hierarchical and masculinised structure (Guerrina, et al 2018: 1; Kronsell 2012: 2015). Hence CSDP represents a hard case for gender mainstreaming due to its unique set-up. This mapping exercise concerning the EEAS' own interpretation of gender mainstreaming in its personnel and in one of the key areas it works on will enable us to underscore the type of gender regime which the EEAS is developing and whether the EEAS is upholding the EU's own normative interpretation of itself as a gender actor.

In order to analyse these two elements we used qualitative content analysis (QCA). The benefit of QCA is that it provides 'a detailed description of the material under analysis' and 'requires the researcher to focus on selected aspects of meaning' (Schrier 2013: 6; 2), which in this instance relates to how and in what context elements of gender are referred to. This gives us insights into which elements of gender the EU refers to within its mainstream security and defence documentation and hiring processes for the EEAS. In turn, this enables us to uncover how the EU understands gender by what it includes, and importantly, the gender silences which result from what it leaves out.

QCA enables the researcher to focus on the key parts of qualitative data, relevant to the research question, in a systematic manner. This is done through creating coding frames which for the purpose of this research, relate to the core components of gender mainstreaming as found in the literature: economics/employment, women in the armed forces, men/boys, inequality, decision-making/representation, equal opportunity, women, mainstreaming and 1325 (see Guerrina and Wright 2016). These are then subsequently refined through the coding process, which involves the integration of gender related sub-categories which relate specifically to mainstreaming in particular areas (CSDP missions/operations, gender experts in CSDP missions/operations, training). Each time an instance within a sentence corresponds to a (sub)category it is coded as such. It should be noted that these instances can relate to the idea underpinning the code. Hence in the case of mainstreaming, the word may be specifically used or the ideas underpinning it may be used. As an example the following sentence is coded as one instance of mainstreaming: 'The EEAS in Brussels, and CSDP missions and operations in 
the field are also cooperating with civil society more broadly, including with human rights and women's rights defenders' (Council of the European Union 2015: 231).

The coding scheme is applied to a range of different documents relating in the first instance to EU personnel in the EEAS including how gender is considered in respect to hiring of staff and where gender actors can be found in the institution itself. Hence this element focuses on where, in terms of personnel, gender can be found. The documents used are the draft and final council decisions setting up the EEAS in addition to the EEAS annual activity report for the years 2011-2015, the 2013 EEAS review and the 2014 human resources report which all partly focus on recruitment to the EEAS.

Secondly, we examined documents relating to CSDP activities- this encompasses documents produced by the EEAS or Council of the European Union in respect to the work of the EEAS. We are focusing on which policy areas and EEAS activities integrate a gender perspective and by extension whether any evidence of mainstreaming can be found. These documents include the HR annual CFSP report (2012-2015) which highlights the main activities of the EEAS, the 2013 and 2014 lessons learnt reports which are the only two which are unclassified and focus on CSDP operations, the 2016 EU Global Strategy (EUGS) which is the key document highlighting the main strategic tasks of the EU in the field of EU external relations and finally the 2016 EUGS implementation plan which emphasises how the CSDP related elements of the EUGS will be enacted. Finally, these results are triangulated with document analysis and five semi-structured interviews which were conducted with officials in Brussels in 2015. The interviews were conducted on the condition of anonymity, hence it is not feasible to state whether these were EU or specific member state officials. 
Figure 1

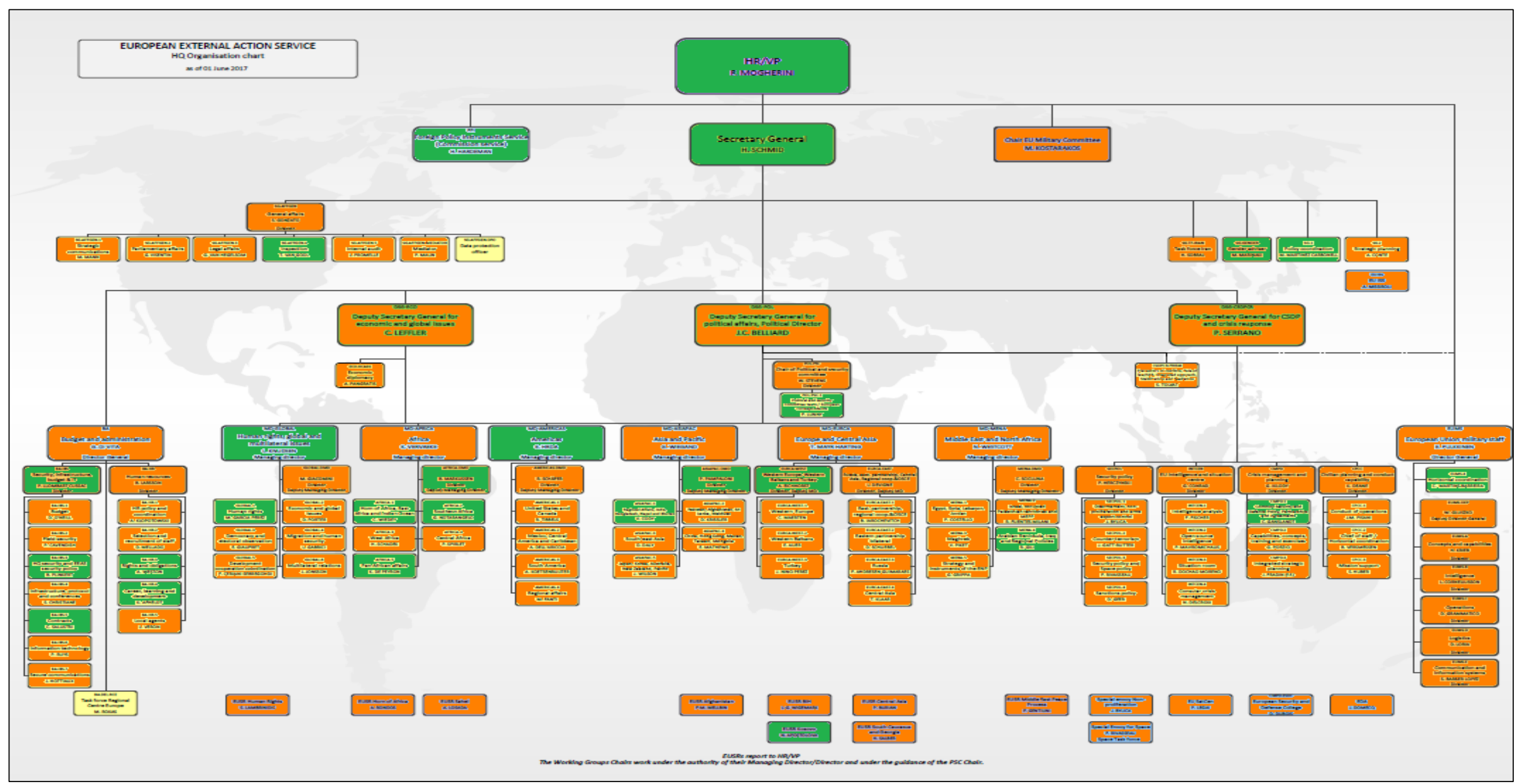

EEAS(2017)Organisation Chart 


\section{Personnel}

The results from the personnel documents (see table 1), underscore a clear pattern. The EEAS' understanding of gender reflects an 'add women and stir' approach in which the aim is to ensure equal numbers of men and women at each level of the institutional structure. This is made clear in the Council Decision setting up the EEAS in which there are clear references to gender as well as geographical balance (Council of the European Union 2010). Interestingly the overall demographic breakdown of the EEAS employees stands at $49 \%$ women and $51 \%$ men, therefore highlighting gender balance in the overall make-up of the institution. However there is a clear pattern of vertical segregation of the labour force within the EEAS whereby women are primarily employed in traditional lower ranking, administrative roles rather than management and/or leadership positions. This ultimately produces an under-representation at higher levels of the organisation (EEAS 2015: 47). Moreover, as highlighted by the EEAS (2013: 8) annual activity report: 'Since the creation of the EEAS, the number of women in Head of Delegation posts has significantly increased from 10 to 31 (23\%). At Headquarters there are more women in management positions of Head of Division and they represent $18 \%$ of the total'. Indeed by 2015 'the share of female managers (i.e. middle and senior management) stood at 21.4 percent' (EEAS 2015: 11). The situation is worse when it comes to seconded national experts primarily due to where they are located - i.e. crisis management structures and in particular the EU Military Staff (EUMS) (EEAS 2015: 53). Indeed the EEAS organigram (figure 1) clearly reflects the lack of women in senior management posts. Overall the documentation supports the idea that increasing gender balance within the institutions will lead to better equality outcomes. This is further underscored by the fact that the words men/women and gender are interchangeable throughout the documentation.

Additional evidence can be garnered through a detailed analysis of the EU's personnel directory, member state permanent representations, and the EU's institute for security studies which detail where women can be found within EEAS structures as well as key CSDP decisionmaking bodies (data collected between July and August 2017). This analysis paints a rather sobering picture. Within the EUMS only 22 out of 176 people listed in the personnel directory are female and of those, 12 are secretaries/assistants. Meanwhile considering the criticism of a lack of gender balance where member state experts are concerned it is unsurprising that the EU Military Committee, of which the chair is the military advisor to the HP/VP and thus appears on the EEAS organigram, is formed only of men, further underscoring the lack of female bodies in military CSDP (see also Kronsell 2015). On the political side of CSDP the situation is not 
much better at the higher level with only five out of 28 member state ambassadors to the Political and Security Committee (PSC), which is chaired by EEAS representatives, being women. Looking below the PSC to the two key sub-committees - Politico-military group (PMG) and the civilian committee (CIVCOM) - however reveals an increased number of women on the military (12 representatives) than the civilian side (9 representatives) (even though the representative for four member states on PMG and two on the CIVCOM are not known). Finally, in the Civilian Planning and Conduct Capability (CPCC), which resides within the EEAS, 23 of the 65 listed personnel are women with 7 of these fulfilling the traditional female role of secretary/assistant compared with 3 men. Indeed there are no female head of section in the CPCC as opposed to the crisis management planning directorate where there is one women out of three heads of section. Hence it appears that politically there are slightly more women on the military than the civilian side of CSDP whereas seconded experts from the military are primarily men with little female representation. Highlighting the lack of gender balance in the committees formed from member states' permanent representations is essential, because it underscores issues of gender equality within the EU member states. This becomes important in the context of the EEAS as one third of its personnel is seconded from the member states, including high ranking positions (such as Head of Delegation posts).

Whilst it has been noted that two women were appointed to the position of High Representative in the developmental stages of the institution, care needs to be taken as having a women at the top of the institution does not in itself ensure equality. The adoption of a gender sensitive approach requires a detailed consideration of structural barriers faced by women operating within highly masculinised fields, e.g. security and defence. The EU's documentation examined here highlights implicit bias with the way the organisation is structured. The one exception appears in Ashton's 2013 report in which she states that 'The most senior woman in the Service is Helga Schmid, who as Political Director is leading a network of women managers in the EEAS to encourage and support the professional development' (EEAS 2013: 14). Thus this places Helga Schmid in the position of a gender champion, promoting a particular type of gender regime - one which focuses on the career progression of women to ensure equal representation although its success appears to be somewhat questionable considering that just one out of nine EU special representatives, no deputy secretary generals, two out of six managing director and four out of eleven deputy managing directors and directors are women (see figure 1). The EEAS' approach however is no surprise considering that this reflects the EU's employability gender regime where the emphasis is placed on equal employment rights. 
Therefore in part there has been a spill-over from DG employment in the Commission into the EEAS' own staffing policy.

Finally a new institutional innovation took place in 2015 with the creation of the Office of the Gender Advisor. Whilst this is a positive development insofar that gender was dealt with only in particular parts of the institution (e.g. CMPD) prior to this innovation, there is the potential issue of creating a gender silo in the EEAS which would not lead to mainstreaming of CSDP. It is important to note that the Gender Advisor does not report to the HR thus potentially undermining their key role in integrating a gender perspective into the EEAS. Overall, the lack of female bodies in the EEAS, particularly in respect to military structures is concerning, as it is these elements which have to implement CSDP policy including gender mainstreaming.

\section{Common Security and Defence Policy - is gender mainstreaming the missing link?}

A superficial analysis of the EEAS policy work would indicate that it is working to integrate gender mainstreaming into CSDP (see table 2). There is an increased policy focus on mainstreaming within both CSDP civilian missions and military operations, which is underpinned in the crisis management procedures (EEAS 2015: 18) and is 'always mentioned' in the first steps in planning (interview with a member state official, Brussels, 2015; Council of the European Union 2015: 208). Additionally the importance of training as well as gender experts is seemingly understood by the EEAS at least on paper.

However, this overlooks some serious problems as underscored in the lessons learnt reports. For example, in the 2013 report it highlights that the 'position of Human Rights and gender (HR\&G) experts should be reinforced to guarantee successful mainstreaming of HR\&G aspects into all Mission activities. This effort is hampered when HR\&G experts are part of Operations Section on equal footing as other Mission experts who tend not to respect their special crosscutting responsibility' (EEAS 2014: 38). Hence there is a problem with how gender advisors and the knowledge they bring are being perceived. Indeed this idea of gender being treated as a 'joke' was highlighted in the interviews which were conducted (Interviews with officials in member state permanent representations, Brussels, 2015). Linking into this is the idea that there is an inflationary use of the topic without having the right impact which leads to push back particularly from the Member States whose representatives are active in the various CSDP committees e.g. the PSC, Political-Military Group and seconded to the EEAS (Interviews with officials in member state permanent representations, Brussels, 2015). 


\begin{tabular}{|c|c|c|c|c|c|c|c|c|c|c|c|c|c|}
\hline $\begin{array}{l}\text { Table } 1 \text { - EEAS and } \\
\text { Personnel }\end{array}$ & $\begin{array}{l}\text { Economics } \\
\text { / } \\
\text { Employme } \\
\text { nt }\end{array}$ & $\begin{array}{l}\text { women in } \\
\text { the armed } \\
\text { forces }\end{array}$ & men/boys & Inequality & $\begin{array}{l}\text { Decision } \\
\text { making/ } \\
\text { representat } \\
\text { ion }\end{array}$ & $\begin{array}{l}\text { Equal } \\
\text { opportunit } \\
\text { y }\end{array}$ & women & GM & $\begin{array}{l}\text { GM - } \\
\text { CSDP } \\
\text { missions/ } \\
\text { operations }\end{array}$ & $\begin{array}{l}\text { GM - } \\
\text { Gender } \\
\text { Experts in } \\
\text { CSDP } \\
\text { missions/ } \\
\text { operations }\end{array}$ & $\begin{array}{l}\text { GM- } \\
\text { Training }\end{array}$ & $\begin{array}{l}\text { UNSCR } \\
1325\end{array}$ & SUM \\
\hline $\begin{array}{l}\text { Ashton draft council decision establishing } \\
\text { the EEAS } 2010\end{array}$ & 0 & 0 & 0 & 0 & 2 & 0 & 0 & 0 & 0 & 0 & 0 & 0 & 2 \\
\hline $\begin{array}{l}\text { Council decision establishing the EEAS } \\
2010\end{array}$ & 0 & 0 & 0 & 0 & 3 & 0 & 0 & 0 & 0 & 0 & 0 & 0 & 3 \\
\hline EEAS Annual Activity Report 2011 & 0 & 0 & 0 & 1 & 0 & 0 & 1 & 0 & 0 & 0 & 0 & 0 & 2 \\
\hline EEAS Annual Activity Report 2012 & 1 & 0 & 0 & 0 & 0 & 0 & 0 & 0 & 0 & 0 & 0 & 0 & 1 \\
\hline EEAS Annual Activity Report 2013 & 1 & 0 & 1 & 0 & 2 & 10 & 2 & 0 & 0 & 0 & 0 & 0 & 16 \\
\hline EEAS Annual Activity Report 2014 & 0 & 0 & 0 & 0 & 0 & 0 & 0 & 0 & 0 & 0 & 0 & 0 & 0 \\
\hline EEAS Annual Activity Report 2015 & 0 & 0 & 0 & 0 & 3 & 0 & 2 & 0 & 0 & 0 & 0 & 0 & 5 \\
\hline EEAS Review 2013 & 0 & 0 & 1 & 0 & 8 & 2 & 6 & 0 & 0 & 0 & 0 & 0 & 17 \\
\hline EEAS Human Resources Report 2014 & 2 & 0 & 24 & 0 & 68 & 2 & 43 & 0 & 0 & 0 & 0 & 0 & 139 \\
\hline SUM & 4 & 0 & 26 & 1 & 86 & 14 & 54 & 0 & 0 & 0 & 0 & 0 & 185 \\
\hline
\end{tabular}


The 2014 report further highlights that 'one of the key obstacles to mainstreaming identified by CSDP Human Rights and Gender Advisers at their annual meeting was lack of management support' (EEAS 2015). Recommendations include placing gender expertise into fact finding missions, that gender should be 'effectively' mainstreamed across all activities in a mission/operation and that it needs to be included in pre-departure training (EEAS 2015: 19). How effectively gender is mainstreamed also depends on who is representing the member states in the various CSDP structures. Having female delegates in the working groups and some female ambassadors in the PSC makes it easier thus underscoring that gender is seen as a woman's issue (Interview with a member state's officials, Brussels, 2015). This links into the importance of gender balance in terms of member state personnel seconded to the EEAS as underscored in the previous section. Hence gender matters not being taken seriously is a major obstacle to the mainstreaming of gender and underscores the lack of a gender norm within the EEAS and CSDP.

Second gender is subsumed under human rights indicating that it is not a key norm in the EU's external relations. The intertwining of these agendas, although mutually reinforcing, silos gender in a specific domain, whereas the point of gender mainstreaming is that it should be treated as a crosscutting issue. Indeed, CSDP missions and operations should have either a human rights or gender expert rather than the latter being made a requirement. Hence half of EU missions currently have a gender advisor (Council of the European Union 2014: 170). The assumptions is that the two positions are interchangeable, thus de-prioritising the importance of gender expertise in the delivery of key objectives. It is also within this context that the frame of 'gender' appears in a list, whether in connection to gender equality, mainstreaming or activities such as training as exemplified by this statement: 'The EEAS should ensure that the Internet Distance Learning pre-deployment training which is currently being developed addresses the issues of human rights, personal ethics, sexual harassment and gender' (EEAS 2014: 9). Hence there is no evidence of the full integration of gender into EU policy documentation and activities. Rather it is 'added in' as a tick box exercise.

Finally, UNSCR 1325 is referred to within the policy documentation however not to the extent that would be presumed considering this is the primary international vehicle for the mainstreaming of gender. For example, the High Representative's report from 2014 underscores that: 'It was active on the issue of women, peace and security in more than 70 countries this year with its support amounting to approximately $€ 200$ million for the 
development and the implementation of national action plans, funding for non-governmental organisations, and training for governmental agencies' (Council of the EU 2013: 122). This statement also implies where the EU is focusing its mainstreaming activities: on funding others to do the work (which fits into the current idea of resilience as articulated in the EU Global Strategy) and training. It should also be highlighted that the implementation of WPS is not necessarily about 'gender equality' but 'it is a means to the goal of security, stabilisation and peace' (Interview with a member state official, Brussels, 2015). This leads to the idea of the co-option of the WPS agenda to underpin other overriding security tasks.

Overall gender has become "a tick box exercise" in the EU's mainstream documentation which is part of a list of areas which the EU should consider. As the EU Global Strategy insightfully underscores: 'we will systematically mainstream human rights and gender issues across policy sectors and institutions (...) Greater awareness and expertise on such issues is needed within the EEAS' (EEAS 2016: 51). This ties in with the importance of gender advisors, training and the mainstreaming of gender whilst reflecting on the obstacles to these developments particularly in terms of the mentality of some member state officials sitting within the EEAS structures. 


\begin{tabular}{|c|c|c|c|c|c|c|c|c|c|c|c|c|c|}
\hline $\begin{array}{lll}\text { Table } & 2 & - \\
\text { CSDP } & & \end{array}$ & $\begin{array}{l}\text { Economics/ } \\
\text { Employment }\end{array}$ & $\begin{array}{l}\text { women in the } \\
\text { armed forces }\end{array}$ & men/boys & Inequality & $\begin{array}{l}\text { Decision } \\
\text { making/ } \\
\text { representatio } \\
\mathrm{n}\end{array}$ & $\begin{array}{l}\text { Equal } \\
\text { opportunity }\end{array}$ & women & GM & $\begin{array}{l}\text { GM- CSDP } \\
\text { missions/oper } \\
\text { ations }\end{array}$ & $\begin{array}{l}\text { GM- Gender } \\
\text { Experts in } \\
\text { CSDP } \\
\text { missions/oper } \\
\text { ations }\end{array}$ & GM- Training & 1325 & SUM \\
\hline $\begin{array}{l}\text { Lessons Learnt Report } \\
2013\end{array}$ & 0 & 0 & 0 & 0 & 1 & 1 & 0 & 0 & 0 & 3 & 5 & 0 & 10 \\
\hline $\begin{array}{l}\text { Lessons Learnt Report } \\
2014\end{array}$ & 0 & 0 & 0 & 0 & 0 & 0 & 0 & 0 & 5 & 8 & 6 & 0 & 19 \\
\hline $\begin{array}{l}\text { HR Annual Report - } \\
\text { CFSP - } 2012\end{array}$ & 0 & 0 & 0 & 0 & 1 & 2 & 3 & 0 & 0 & 0 & 0 & 3 & 9 \\
\hline $\begin{array}{l}\text { HR Annual Report - } \\
\text { CFSP } 2013\end{array}$ & 0 & 0 & 0 & 0 & 2 & 2 & 6 & 4 & 1 & 1 & 3 & 3 & 22 \\
\hline $\begin{array}{l}\text { HR Annual Report - } \\
\text { CFSP } 2014\end{array}$ & 0 & 0 & 0 & 1 & 0 & 3 & 8 & 2 & 5 & 4 & 2 & 2 & 27 \\
\hline $\begin{array}{l}\text { HR Annual Report - } \\
\text { CFSP } 2015\end{array}$ & 0 & 0 & 0 & 0 & 3 & 2 & 13 & 3 & 3 & 3 & 2 & 7 & 36 \\
\hline $\begin{array}{l}\text { Global Security } \\
\text { Strategy } 2016\end{array}$ & 0 & 1 & 1 & 1 & 3 & 2 & 3 & 5 & 0 & 0 & 0 & 1 & 17 \\
\hline $\begin{array}{l}\text { EUGS Implementation } \\
\text { plan } 2016\end{array}$ & 0 & 0 & 0 & 0 & 0 & 0 & 0 & 3 & 0 & 0 & 0 & 2 & 5 \\
\hline SUM & 0 & 1 & 1 & 2 & 10 & 12 & 33 & 17 & 14 & 19 & 18 & 18 & 145 \\
\hline
\end{tabular}




\section{Conclusion}

An analysis of where gender is located within the EEAS and how gender has been mainstreamed into the work and the structures of this institution highlights how the values embedded within the EU's gender regime are integrated into an intergovernmental area. The neo-liberal foundations of the EU permeate the way the EEAS incorporates the principle of equality along the lines of the "add women and stir" principle. Moreover, just like in the case of employment, gender equality becomes a policy objective when it is clear that it provides value added to the primary policy aspirations. The analysis of the EEAS provides important insights into the processes for mainstreaming gender into areas that are traditionally portrayed as gender free. It is interesting to note the institutional obstacles faced by key actors operating within the EEAS in including equality policies into this area. Outlining the processes and mechanisms that make up the institution helps us to understand the values and biases of the organization and the kind of gender regime it is becoming.

Therefore women's under-representation in the institutions remain a significant issue, despite the fact that women have been at the helm of the organization. In this context, the EEAS has sought to mainstream gender by focusing on employment practices and structures of the EEAS itself. This is in keeping with the approach espoused by EU institutions operating within the communitised areas. However, GM has not been incorporated within the EEAS as a form of governance aimed at unpacking the way security and defence are gendered. This supports Connell's (2005) conclusion that whereas gender mainstreaming has placed responsibility on organisations to consider the implications of policy actions on equality, it has not increased their capacity for dealing with gender a system that organises social and economic relations. What this analysis finds is that although the EU claims to be a normative gender actor, as outlined in its use of equality as a foundational myth (Guerrina et al 2018; Guerrina \& Wright, 2016), it is actually a gendered normative actor, meaning that it strategically co-opts gender narratives to promote the interests of the organisation. Hence this reflects the gender regime found in other areas of the EU. Thus the EU's understanding of gender equality is rather shallow, focused on adding women into existing structures rather than offering a transformative approach which unpacks the power structures on which the EEAS rests and mainstreams gender fully into its activities thus living up to its transformative potential.

This analysis also has important implication for the institutionalization of both gender mainstreaming and the WPS agenda. It raises important questions about the way WPS helps to 
transform institutions whilst being transformed itself by the process of "translation" that takes place when international (security) organisations adopt WPS as part of a wider policy framework. This analysis therefore provides important insights into opportunities and constraints for mainstreaming gender in foreign policy, security policy and global governance more generally. The way regional and security organisations include gender has repercussions for the kind of gender actor are and might become through the inclusion of a wider understanding of security and external affairs. 


\section{References}

Bátora, J. (2014), 'The 'Mitrailleuse Effect': The EEAS as an Interstitial Organization and the Dynamics of Innovation in Diplomacy', Journal of Common Market Studies, 51(4), pp 598-613.

Cavaghan, R (2016), 'Bridging Rhetoric and Practice; New Perspectives and Barriers to Gendered Change', Journal of Women, Politics and Policy, 38(1), pp42-63.

Connell, R. (2005) “Advancing Gender Reform in Large Scale Organisations: A New Approach for Practitioners and Researchers", Policy and Society, 24(4), pp 5-24.

Council of the European Union (2010). Draft Council decision establishing the organization and functioning of the European External Action Service, 8029/10 (2010). Brussels: Council of the European Union.

Council of The European Union. (2010a). Council Decision of 26 July 2010 establishing the organization and functioning of the European External Action Service (2010/427/EU), Official Journal of the European Union L201 30-40 (2010). Brussels: Council of the European Union.

Council of the European Union (2012). Main aspects and basis choices of the CFSP 2011, 14605/1/12. Brussels.

Council of the European Union (2013). Main aspects and basis choices of the CFSP 2012, 14924/13. Brussels.

Council of the European Union (2014). Main aspects and basis choices of the CFSP 2013, 12094/14. Brussels

Council of the European Union (2014a). Annual 2013 CSDP Lessons Report, 8015/14, Brussels.

Council of the European Union (2015). Main aspects and basis choices of the CFSP 2014. 11083/15. Brussels.

Council of the European Union (2015a). Annual 2014 CSDP Lessons Report, 6777/15. Brussels.

Council of the European Union (2016). Implementation Plan on Security and Defence, 14392/16. Brussels.

David, M., \& Guerrina, R. (2013). Gender and European external relations: Dominant discourses and unintended consequences of gender mainstreaming. Women's Studies International Forum, 39, 53-62. 
Davis Cross, M. . (2011). Building a European Diplomacy: Recruitment and Training to the EEAS. European Foreign Affairs Review, 16(4), 447-464.

Duke, S. (2012). Diplomatic Training and the Challenges Facing the EEAS. The Hague Journal of Diplomacy, 7(1), 95-114.

Duke, S. (2014). Reflections on the EEAS Review. European Foreign Affairs Review, 19(1), 23044.

EEAS (2011). Annual Activity Report, Brussels

EEAS (2012). Annual Activity Report, Brussels

EEAS (2013). Annual Activity Report, Brussels

EEAS (2013a). EEAS Review, Brussels

EEAS (2014). Annual Activity Report, Brussels

EEAS (2015). Annual Activity Report, Brussels

EEAS (2015a). EEAS Human Resources Report 2014. Brussels.

EEAS (2016). Shared Vision, Common Action: A Stronger Europe. A Global Strategy for the European Union's Foreign And Security Policy, Brussels.

EEAS (2017). Organisation Chart. 1 June. Available at: https://eeas.europa.eu/headquarters/ headquarters-homepage/3602/organisation-chart-ofthe-eeas_en (accessed 6 July 2017).

Furness, M. (2013). Who Controls the European External Action Service? Agent Autonomy in EU External Policy. European Foreign Affairs Review, 18(1), 103-126.

Forsberg, T. (2011). 'Normative Power Europe, Once Again: A Conceptual Analysis of an Ideal Type" Journal of Common Market Studies, 49 (6): 1183-1204.

Guerrina, R. (2005). Mothering the Union: Gender Politics in the EU. Manchester University Press.

Guerrina, R; Chappell, L. and Wright, K (2018). 'Transforming CSDP? Feminist Triangles and Gender Regimes', Journal of Common Market Studies, 1-17.

Guerrina, R. and Wright, K (2016) 'Gendering Normative Power Europe: Lessons of the Women, Peace and Security agenda'. International Affairs, 92(2), 293-312.

Henökl, T. E. (2015). How do EU Foreign Policy-Makers Decide? Institutional Orientations within the European External Action Service. West European Politics, 38(3), 679-708. Jaquette, J. S. (2011). Problems, Norms and Global Governance: An Engagement with Jacqui 
True. In J. A. Tickner \& L. Sjoberg (Eds.), Feminism and International Relations: Conversations about the Past, Present and Future. Routledge.

Juncos, A. E., \& Pomorska, K. (2014). Manufacturing Esprit de Corps: The Case of the European External Action Service. Journal of Common Market Studies, 52(2), 302-319.

Juncos, A.E. and Pomorska, K (2013), 'In the face of adversity: explaining the attitudes of EEAS officials vis-à-vis the new service', Journal of European Public Policy, 20 (9), pp1332-1349.

Kronsell, A (2015). 'Sexed Bodies and Military Masculinities: Gender Path Dependence in EU's Common Security and Defense Policy'. Men and Masculinities, Vol. 19, No. 3, 126.

Kronsell, A. (2012). Gender, Sex and Post-National Defence. Oxford University Press.

Minto, R. and Mergaert, L (2018) "Gender Mainstreaming and Evaluation in the EU: Comparative Perspectives from Feminist Institutionalism”, International Feminist journal of Politics,

MacRae, H. (2010). The EU as a Gender Equal Polity: Myths and Realities. Journal of Common Market Studies, 48(1), 155-174.

Manners, I. (2002). Normative Power Europe: A Contradiction in Terms?. Journal of Common Market Studies, 40(2), 235-258.

Pollack, M. and Hafner-Burton, (2000) “Gender Mainstreaming in the European Union", Journal of European Public Policy, Vol. 7(1)

Pomorska, K and Vanhoonacker, S (2015), 'Resisting the European External Action Service', European Foreign Affairs Review, 20(2/1), 21-38.

O'Connor, J.S. (2014). "Gender mainstreaming in the European Union: broadening the possibilities for gender equality and/or an inherently constrained exercise?" Journal of International and Comparative Social Policy, 30(1), 68-78

Ruane, A. E. (2011). Women's Human Rights and the United Nations. In J. A. Tickner \& L. Sjoberg (Eds.), Feminism and International Relations: Conversations about the Past, Present and Future. Abingdon: Routledge.

Schrier, M. (2013). 'Qualitative Content Analysis', In Flick, Uwe (ed), The Sage Handbook of Qualitative Data Analysis, London: Sage, 170-183.

Shepherd, A.J.K (2016), 'CSDP and the internal-external security nexus'. In Chappell, L, Mawdsley, J and Petrov $\mathrm{P}$ (eds), The EU, Strategy and Security Policy. Regional and strategic challenges, Abingdon: Routledge, 87-103. 
Smith, M. E. (2013). The European External Action Service and the security-development nexus: organizing for effectiveness of incoherence. Journal of European Public POlicy, 20(9), 1299-1315.

Spence, D. (2012). The early days of the european external action service: a practitioner's view, 7, 115-134.

Stratigaki, M. (2004). The Cooptation of Gender Concepts in EU Policies: The Case of "Reconciliation of Work and Family." Social Politics: International Studies in Gender, State \& Society, 11(1), 30-56.

Vanhoonacker, S., \& Pomorska, K. (2013). The European External Action Service and agendasetting in European foreign policy. Journal of European Public Policy, 20(9), 1316-1331. Vanhoonacker, S., \& Reslow, N. (2010). The European External Action Service: Living Forwards by Understanding Backwards. European Foreign Affairs Review, 15(1), 1-18.

Walby, S. (2004). The European Union and Gender Equality: Emergent Varieties of Gender Regime. Social Politics, 11(1), 4-29.

Walby, S. (2009). Globalization and Inequalities: Complexity and Contested Modernities. London: Sage.

Wessel, R., \& Van Vooren, B. (2013). The EEAS's diplomatic dreams and the reality of European and international law. Journal of European Public Policy, 9, 1350-1367.

Whitman, R. (2011). Norms, Power and Europe: A New Agenda for Study of the EU and International Relations. In R. Whitman (Ed.), Normative Power Europe: Empirical and Theoretical Perspectives, Basingstoke: Palgrave Macmillan, 1-24.

Woodward, A. E., \& van der Vleuten, A. (2014). EU and the Export of Gender Equality Norms: Myth and Facts. In A. van der Vleuten, A. van Eerdewijk, \& C. Roggeband (Eds.), Gender Equality Norms in regional Governamnce: Transnational Dynamics in Europe, South America and Southern Africa. Basingstoke: Palgrave Macmillan. 